\title{
FREQUENCY AND DETERMINANTS OF DENTAL CARIES IN LOCAL INHABITANTS OF A RURAL DISTRICT OF KHYBER PAKHTUNKHWA PAKISTAN
}

\author{
Muhammad Naeem¹, Muhammad Ishtiaq², Atif Hussain ${ }^{3}$, Bushra ljaz $^{4}$, Bushra Iftikhar ${ }^{1}$, Imran Marwat ${ }^{1}$ \\ ${ }^{1}$ Department of Community Medicine, Khyber Medical College, Peshawar - Pakistan \\ ${ }^{2}$ Department of Community Medicine, Northwest School of Medicine, Peshawar - Pakistan \\ ${ }^{3}$ Department of Anatomy, Women Medical \& Dental College, Abbottabad - Pakistan \\ ${ }^{4}$ Department of Community Medicine, Multan Medical \& Dental College, Multan - Pakistan
}

\begin{abstract}
Objective: The objective of this study was to assess the frequency and determinants of dental caries in local inhabitants of a rural district of Khyber Pakhtunkhwa Pakistan

Materials and Methods: A cross-sectional survey was conducted in Lower Dir District of Khyber Pakhtunkhwa from September 2018 to February 2019. After taking ethical approval and informed consent from the participants, a total of 149 male adults were assessed regarding the frequency and determinants of dental caries through a self-developed survey tool validated by experts. The study participants were assessed for dental caries by a qualified dental surgeon and data was entered in Microsoft Excel, analyzed, and presented in form of tables.

Results: Our results revealed that $59.73 \%$ of the study population was in the age range of $25-45$ years, $16.78 \%$ had a monthly income of less than Rs. 15000 and $48.99 \%$ were illiterate. Moreover, $69.13 \%$ were aware of the causes of dental caries, $69.80 \%$ used toothbrushes, $25 \%$ brushed their teeth twice daily, and $54.36 \%$ used fluoride toothpaste. Furthermore, $70.47 \%$ had a preference for sweet foods and carbohydrates, and $54.36 \%$ had poor oro-dental hygiene.

Conclusions: One-third of the studied population was suffering from dental caries. The different determinants identified in the survey were low socio-economic status, illiteracy, poor tooth brushing practices, and the use of fluoride toothpaste. Moreover, sweet food preference and oral hygiene status were frequently seen in patients with dental caries. Effective preventive, promotive, and curative services are needed to reduce dental caries and their complications.
\end{abstract}

Key Words: Dental Caries, Toothbrush, Oro-Dental Hygiene.

This article may be cited as: Naeem M, Ishtiaq M, Hussain A, Ijaz B, Iftikhar B, Marwat I. Frequency and Determinants of Dental Caries in Local Inhabitants of a Rural District of Khyber Pakhtunkhwa Pakistan. J Med Sci 2021 January;29(1):30-33

\section{INTRODUCTION}

Oral and dental hygiene is one of the significant aspects of body fitness and thus has a strong role in physical, social, and mental well-being ${ }^{1}$. The prevalence of dental caries varied among the countries and showed a strong difference between the developed and developing countries; and ranged from $2 \%$ to $20 \%$ among developed and up to more than $60 \%$ among the developing countries $^{2,3}$. Dental caries are a widespread disease, affecting billions of people worldwide 4 .

\section{Correspondence}

Dr. Muhammad Ishtiaq

Department of Community Medicine

Northwest School of Medicine, Peshawar- Pakistan

Email: drishtiaq250@yahoo.com

Cell: +92-0334-9121822

Date received: $27-10-2020$

Date revised: $02-01-2021$

Date accepted: $02-02-2021$
The burden of dental caries varies among different Asian regions and has 35\% to $72 \%$ prevalence among Eastern, Western, and Southern Asian countries ${ }^{5}$. Dental caries critically impact the health and development of children $^{6}$. Research showed that there is a strong relationship between oro-dental hygiene status and parental knowledge, attitude, and perceptions ${ }^{7}$. Moreover, some etiological factors of dental caries are; fluids with a high quantity of sugar, honey, or sugar used for sweetening purposes, and unhealthy dental and mouth hygiene status ${ }^{8,9}$.

It affects $50 \%$ of populations in any country ${ }^{10}$. An international study showed a consistent positive association of dental problems with risk factors like sweet food items $^{11,12}$. There is also a strong relationship between breastfeeding and dental problems, and a study revealed a nonlinear relationship between duration of breastfeeding and dental problems ${ }^{13}$. 
Frequency And Determinants Of Dental Caries In Local Inhabitants Of A Rural District Of Khyber Pakhtunkhwa Pakistan.

Dental caries are a common health problem among local communities of Pakistan. This survey aimed to assess the frequency of dental caries and their risk factors among male adults of District Lower Dir, Khyber Pakhtunkhwa Pakistan. The findings of this study will help the clinicians in developing strategies to prevent and treat dental caries in the local population.

\section{MATERIALS AND METHODS}

This descriptive cross-sectional survey was conducted from September 2018 to February 2019 in the Lower Dir District of Khyber Pakhtunkhwa. After taking ethical approval from the institute and informed consent from participants, a total of 149 male adults were surveyed regarding the frequency \& determinants of dental caries. Only male adults and permanent residents of district Lower Dir were included. The District Lower Dir has a population of 1.44 Million with a total area of $1582 \mathrm{~km}^{2}$. The survey tool was developed and validated by expert discussion and pilot testing among 15 participants. The survey questionnaire comprised of two sections, in which one was related to the demographic variables like age, monthly income, education status, number of children of participants, and home conditions, while the second section had ten survey items, of which six had yes/no responses and the remaining four items had three responses. The study participants were assessed for the presence or absence of dental caries by a qualified dental surgeon with more than five years of clinical experience. Data were analyzed in Microsoft Ex-

Table 1: Demographic Characteristics of the Study Population $(n=149)$ Of District Lower Dir

\begin{tabular}{|c|c|c|c|}
\hline $\begin{array}{c}\text { Demographic Vari- } \\
\text { ables }\end{array}$ & Results & Frequency & $\%$ \\
\hline \multirow[t]{4}{*}{ Age Groups } & 15 - 25 years & 34 & 22.82 \\
\hline & 25 - 35 years & 51 & 34.23 \\
\hline & 35 - 45 years & 38 & 25.50 \\
\hline & $46 \&$ above & 26 & 17.45 \\
\hline \multirow[t]{4}{*}{ Monthly Income } & $<15000$ & 25 & 16.78 \\
\hline & 15000 - 25000 & 46 & 30.87 \\
\hline & 25000 - 35000 & 33 & 22.15 \\
\hline & $>35000$ & 45 & 30.20 \\
\hline \multirow[t]{4}{*}{ Educational Status } & Illiterate & 73 & 48.99 \\
\hline & Middle & 35 & 23.49 \\
\hline & Secondary & 27 & 18.12 \\
\hline & FA/BA \& Above & 14 & 9.40 \\
\hline \multirow{2}{*}{$\begin{array}{l}\text { House Structure } \\
\text { Made of }\end{array}$} & Cemented & 105 & 70.47 \\
\hline & Mud etc & 44 & 29.53 \\
\hline \multirow[t]{3}{*}{ No of Children } & $1 \& 2$ & 78 & 52.35 \\
\hline & $3 \& 4$ & 43 & 28.86 \\
\hline & $>4$ & 28 & 18.79 \\
\hline
\end{tabular}

cel and presented in tabulated form.

\section{RESULTS}

The demographic characteristic of the study population was shown in Table No 1. The frequency of dental caries among the study population was $31.54 \%$. The determinants of dental caries among the study population are shown in Table No 2.

Table 2: Determinants of Dental Caries among Study Population $(n=149)$ District Lower Dir

\begin{tabular}{|c|c|c|c|c|}
\hline \multirow[t]{2}{*}{ S.No } & \multirow[t]{2}{*}{ Survey Items } & \multirow[t]{2}{*}{ Response } & \multicolumn{2}{|c|}{$n=149$} \\
\hline & & & Frequency & (\%age) \\
\hline \multirow[t]{2}{*}{1} & \multirow{2}{*}{$\begin{array}{l}\text { Do you know } \\
\text { the causes of } \\
\text { dental caries? }\end{array}$} & Yes & 103 & 69.13 \\
\hline & & No & 46 & 30.87 \\
\hline \multirow[t]{2}{*}{2} & \multirow{2}{*}{$\begin{array}{l}\text { Do you have } \\
\text { any dental prob- } \\
\text { lem currently? }\end{array}$} & Yes & 16 & 10.74 \\
\hline & & No & 133 & 89.26 \\
\hline \multirow[t]{2}{*}{3} & \multirow{2}{*}{$\begin{array}{l}\text { Do you tooth- } \\
\text { brush teeth? }\end{array}$} & Yes & 104 & 69.80 \\
\hline & & No & 45 & 30.20 \\
\hline \multirow[t]{3}{*}{4} & \multirow{3}{*}{$\begin{array}{l}\text { Frequency of } \\
\text { your toothbrush } \\
\text { use per day }\end{array}$} & 1 time & 71 & 68.27 \\
\hline & & 2 times & 27 & 25.96 \\
\hline & & $>2$ times & 6 & 5.77 \\
\hline \multirow[t]{2}{*}{5} & \multirow{2}{*}{$\begin{array}{l}\text { You use fluoride } \\
\text { toothpaste }\end{array}$} & Yes & 81 & 54.36 \\
\hline & & No & 68 & 45.64 \\
\hline \multirow[t]{3}{*}{6} & \multirow{3}{*}{$\begin{array}{l}\text { Frequency of } \\
\text { fluoride tooth } \\
\text { paste you use } \\
\text { per day }\end{array}$} & 1 time & 48 & 59.26 \\
\hline & & 2 times & 27 & 33.33 \\
\hline & & $>2$ times & 6 & 7.41 \\
\hline \multirow[t]{2}{*}{7} & \multirow{2}{*}{$\begin{array}{l}\text { Do you prefer } \\
\text { carbohydrate } \\
\text { and sweets? }\end{array}$} & Yes & 105 & 70.47 \\
\hline & & No & 44 & 29.53 \\
\hline \multirow[t]{2}{*}{8} & \multirow{2}{*}{$\begin{array}{c}\text { Do you consult } \\
\text { dentist regu- } \\
\text { larly? }\end{array}$} & Yes & 65 & 43.62 \\
\hline & & No & 84 & 56.38 \\
\hline \multirow[t]{3}{*}{9} & \multirow{3}{*}{$\begin{array}{l}\text { When you con- } \\
\text { sulted dentist } \\
\text { for yourself? }\end{array}$} & For problem & 51 & 34.23 \\
\hline & & Regular & 14 & 9.40 \\
\hline & & None & 84 & 56.38 \\
\hline \multirow[t]{3}{*}{10} & \multirow{3}{*}{$\begin{array}{l}\text { Status of oral } \\
\text { hygiene }\end{array}$} & Poor & 81 & 54.36 \\
\hline & & Satisfactory & 48 & 32.21 \\
\hline & & Good & 20 & 13.42 \\
\hline
\end{tabular}

\section{DISCUSSIONS}

In our study, the frequency of dental caries was found to be $31.54 \%$, where internationally the prevalence ranges from 20 to $50 \% 5,14,15,16$. Our study findings are consistent with a study conducted in Saudi Arabia, where the frequency was $30.22 \%{ }^{1}$.

In our study, $83.22 \%$ had a monthly income of more than PKR 15000. This population showed a lower 
Frequency And Determinants Of Dental Caries In Local Inhabitants Of A Rural District Of Khyber Pakhtunkhwa Pakistan.

frequency of caries which is consistent with international studies that highlight the relationship of high income with lower risk of dental caries ${ }^{17,18}$. Moreover, the education status played a great role in the development of dental caries, as educated families had better opportunities and had less prevalence of dental caries as was reported by our study in which more than half of the study population was educated and thus showed less prevalence ${ }^{12}$.

International studies revealed that education plays a positive relationship with improved oral hygiene ${ }^{3,19}$. Moreover, food intake is an indirect tool to determine dental caries in a family or community. In our study, only $29.53 \%$ of families were following healthy food diets whereas in an international study, 92\% of participants were following healthy foods ${ }^{1}$. Many international studies showed the same significant relationship of sugars-based diet preferences with dental caries ${ }^{20,21}$. Furthermore in our study, $66.67 \%$ of children used fluoride toothpaste, and thus had less frequency as compared to studies which showed $98.5 \%$ and $86 \%{ }^{10,22}$.

Our study was limited to a single district and had fewer participants which limit its generalizability. Further large-scale multicenter cohort studies are needed to find the causal effects of these determinants in causing dental caries.

\section{CONCLUSIONS}

One-third of the studied population was suffering from dental caries. The different determinants identified in the survey were low socio-economic status, illiteracy, poor tooth brushing practices, and the use of fluoride toothpaste. Moreover, sweet food preference and oral hygiene status were frequently seen in patients with dental caries. Effective preventive, promotive, and curative services are needed to reduce dental caries and their complications.

\section{REFERENCES}

1. Alshehri A, Nasim VS. Infant oral health care knowledge and awareness among parents in Abha city of Aseer Region, Saudi Arabia.The Saudi journal for dental research. 2015 Jul 1;6(2):98-101.

2. Hooley M, Skouteris H, Boganin C, Satur J, Kilpatrick N. Parental influence and the development of dental caries in children aged 0-6 years: a systematic review of the literature. Journal of dentistry. 2012 Nov 1;40(11):873-85.

3. González E, Pérez-Hinojosa S, Alarcón JA, Peñalver MA.Knowledge of Andalusianpaediatricians and parents about early-onset tooth decay.Anales de Pediatría (English Edition). 2015 Jan 1;82(1):19-26.
4. Selwitz RH, Ismail Al, Pitts NB. Dental caries. The Lancet. 2007 Jan 6;369(9555):51-9.

5. Almoudi M, Hussein A, Hassan MA, Schroth R. Dental caries and vitamin $D$ status in children in Asia. Pediatrics International. 2019 Apr 1;61(4):327-38.

6. Al Agili DE. A systematic review of population-based dental caries studies among children in Saudi Arabia. The Saudi Dental Journal. 2013 Jan 1;25(1):3-11.

7. Alshehri A. Social and Behavioral Determinants of Early Childhood Caries in the Aseer Region of Saudi Arabia. MJ Dent. 1 (2): 008.

8. M.J. Tiberia, A.R. Milnes, R.J. Feigal, K.R. Morley, D.S. Richardson, W.G. Croft, et al. Risk factors for early childhood caries in Canadian preschool children seeking care. Pediatr Dent, 29 (2007), pp. 201-208. Medline.

9. S.Z. Mohebbi, J.I. Virtanen, H. Murtomaa, M. Vahid-Golpayegani, M.M. Vehkalahti. Mothers as facilitators of oral hygiene in early childhood. Int $\mathrm{J}$ Paediatr Dent, 18 (2008), pp. 48-55. http://dx.doi.org/10.1111/j.1365263X.2007.00861.x | Medline.

10. Saldūnaitè K, Bendoraitienè EA, Slabšinskienè E, Vasiliauskienè I, Andruškevičienè V, Zūbienè J. The role of parental education and socioeconomic status in dental caries prevention among Lithuanian children. Medicina. 2014 Jul 29;50(3):156-61. 10

11. Pitts NB, Zero DT, Marsh PD, Ekstrand K, Weintraub JA, Ramos-Gomez F, Tagami J, Twetman S, Tsakos G, Ismail A. Dental caries. Nature reviews Disease primers. 2017 May 25;3:17030.

12. Dye BA, Mitnik GL, lafolla TJ, Vargas CM. Trends in dental caries in children and adolescents according to poverty status in the United States from 1999 through 2004 and from 2011 through 2014. The Journal of the American Dental Association. 2017 Aug 1;148(8):550-65.

13. Ha DH, Spencer AJ, Peres KG, Rugg-Gunn AJ, Scott JA, Do LG. Fluoridated Water Modifies the Effect of Breastfeeding on Dental Caries. Journal of dental research. 2019 Apr 11:0022034519843487.

14. Tham R, Bowatte G, Dharmage SC, Tan DJ, Lau MX, Dai $\mathrm{X}$, Allen KJ, Lodge CJ. Breastfeeding and the risk of dental caries: a systematic review and meta-analysis. ActaPaediatrica. 2015 Dec;104:62-84.

15. Schroth RJ, Rabbani R, Loewen G, Moffatt ME. Vitamin D and dental caries in children. Journal of dental research. 2016 Feb;95(2):173-9.

16. Wyne $\mathrm{AH}$. The bilateral occurrence of dental caries among 12-13 and 15-19 year old school children. J Contemp Dent Pract. 2004 Feb 15;5(1):42-52. 
Frequency And Determinants Of Dental Caries In Local Inhabitants Of A Rural District Of Khyber Pakhtunkhwa Pakistan.

17. Marinho VC, Chong LY, Worthington HV, Walsh T. Fluoride mouthrinses for preventing dental caries in children and adolescents. Cochrane Database of Systematic Reviews. 2016(7).

18. Ferreira FM, Gomes MC, Granville-Garcia AF, Santin GC, Pintarelli TP, Feltrin J, Fraiz FC. How much does household food insecurity explain income inequalities in untreated dental caries?. International journal of paediatric dentistry. 2019 Jan 21.

19. Halawany HS, Abraham NB, Jacob V, Al-Maflehi N. The perceived concepts of oral health attitudes and behaviors of dental students from four Asian countries. The Saudi Journal for Dental Research. 2015 Jul 1;6(2):7985.

20. Baghlaf K, Muirhead V, Moynihan P, Weston-Price S, Pine C. Free Sugars Consumption around Bedtime and Dental Caries in Children: A Systematic Review. JDR Clinical \& Translational Research. 2018 Apr;3(2):118-29.

21. Masson LF, Blackburn A, Sheehy C, Craig LC, Macdiarmid JI, Holmes BA, McNeill G. Sugar intake and dental decay: results from a national survey of children in Scotland. British journal of nutrition. 2010 Nov;104(10):155564.
22. Jiang EM, Lo EC, Chu CH, Wong MC. Prevention of early childhood caries (ECC) through parental tooth-brushing training and fluoride varnish application: a 24-month randomized controlled trial. Journal of dentistry. $2014 \mathrm{Dec}$ 1;42(12):1543-50.

CONFLICT OF INTEREST: Authors declare no conflict of interest

GRANT SUPPORT AND FINANCIAL DISCLOSURE: NIL

\section{AUTHOR'S CONTRIBUTION}

Following authors have made substantial contributions to the manuscript as under

Naeem M: Concept and Design.

Ishtiaq M: Acquisition and critical review.

Hussain A: Data collection.

ljaz B: Data collection.

Iftikhar B: Concept and Design.

Marwat I: $\quad$ Analysis and interpretation of data.

Authors agree to be accountable for all aspects of the work in ensuring that questions related to the accuracy or integrity of any part of the work are appropriately investigated and resolved. 